Relations industrielles

Industrial Relations

\title{
Eléments de sociologie hospitalière, par Paul Swertz, Paris, Le Centurion, 1974, 132 pp.
}

\section{Gilles Dussault}

Volume 30, numéro 1, 1975

URI : https://id.erudit.org/iderudit/028599ar

DOI : https://doi.org/10.7202/028599ar

Aller au sommaire du numéro

Éditeur(s)

Département des relations industrielles de l'Université Laval

ISSN

0034-379X (imprimé)

1703-8138 (numérique)

Découvrir la revue

Citer ce compte rendu

Dussault, G. (1975). Compte rendu de [Eléments de sociologie hospitalière, par Paul Swertz, Paris, Le Centurion, 1974, 132 pp.] Relations industrielles /

Industrial Relations, 30(1), 128-129. https://doi.org/10.7202/028599ar

Tous droits réservés @ C Département des relations industrielles de l'Universite Laval, 1975
Ce document est protégé par la loi sur le droit d'auteur. L'utilisation des services d'Érudit (y compris la reproduction) est assujettie à sa politique d'utilisation que vous pouvez consulter en ligne.

https://apropos.erudit.org/fr/usagers/politique-dutilisation/ 
tre aspect que néglige de traiter en profondeur l'auteur du présent ouvrage. Sur ce plan, l'auteur traite effectivement du travail d'équipe et de l'adoption d'une philosophie participative du management découlant de la théorie $\mathrm{Y}$ de McGregor comme autant de prérequis à l'instauration du système, mais ne s'aventure pas dans une explication du lien qui peut exister entre une phisolophie participative et la nature de la participation inhérente à la gestion par objectifs.

Une autre dimension m'apparaît aussi escamotée : celle du lien qui existe entre la motivation des dirigeants et la gestion par objectifs. On retrouve au cours d'un chapitre un parallèle entre les besoins des dirigeants et la manière dont la gestion par objectifs peut les satisfaire. Cependant, l'auteur fait peu de place dans le système qu'il présente aux aspirations personnelles des dirigeants en termes d'avancement et développement personnel, puisque la définition d'objectifs se limite aux postes administratifs et non aux individus qui en sont les titulaires.

\section{Université Laval}

Labour Relations Law, Cases-Materials and Commentary, The Labour Relations Law Casebook Group, Second Edition, Kingston, Queen's University Press, 1974, 589 pp.

La réputation de ce casebook n'est plus à faire. La première édition (1970) avait su s'attirer d'élogieux commentaires. La seconde édition en est une repensée. On notera notamment que les matières qui sous-tendent la compréhension des rapports collectifs du travail sont traités de façon différente et plus approfondie. De plus, et c'est là le principal mérite de la nouvelle édition, plusieurs sujets concernant la négociation collective ont été rajoutés ou complétés.

L'ouvrage est présenté en dix thèmes : 1) The Issues (p. 1); 2) The Emergence of Collective Bargaining as Basic Public Policy in Canadian Labour Relations (p. 7) ; 3) The Right to Join a Union (p. 43) ; 4) Status Under Collective Bargaining Legislation ( $p .46) ; 5$ ) The Establishment and Termination of Collective Bargaining Rights (p. 125);
6) The Collective Bargaining/Relationship (p. 184) ; 7) The Collective Agreement and its Administration (p. 238) ; 8) Industrial Conflict: Strikes, Picketing, Boycotts and Lockouts (p. 400) ; 9) Inter-Union Rivalry Regarding Membership and Work Jurisdiction ( $p$. 496) ; 10) The Union and Those Subject to its Authority; Internal Union Affairs (p. 524).

Chacun des grands thèmes regroupent différents sous-thèmes dont on peut trouver les intitulés à la table des matières. Cette forme de présentation rend l'ouvrage d'utilisation simple et rapide dans la mesure où l'utilisateur entend lire le sous-thème en entier. On regrette l'absence d'un index analytique dont le grand mérite est de permettre de localiser rapidement un sujet particulier qui peut être abordé à différents sous-thèmes.

Le Labour Relations Law reste essentiellement un casebook. Il n'est ni un traité, ni un précis, ni un manuel sur le droit des relations du travail. Le choix des articles de doctrinales et des espèces jurisprudentielles qui sont rapportées dans cet ouvrage semble très judicieux. Les commentaires des auteurs situent particulièrement bien le lecteur. Les références faites à la législation étaient de mise. Ce casebook ne semble avoir été conçu ni pour des fins purement pédagogiques, ni pour des fins simplement pratiques. Il tente de se situer à mi-chemin entre ces deux objectifs et y réussit fort bien.

Le groupe de travail qui a signé l'ouvrage est constitué de H.W. Arthurs, P. Weiler, B. Adell et I. Christie, G. Adams et K. Norman. Ces éminentes autorités sont, pour le lecteur, une garantie du sérieux du document que l'on ne peut que fortement suggérer aux québécois de consulter pour fin d'études de droit comparé.

\section{Université Laval}

Rodrigue BLOUIN

Eléments de sociologie hospitalière, par Paul Swertz, Paris, Le Centurion, 1974, 132 pp.

Ce petit livre, dont l'édition originale allemande date de 1970 , s'adresse spécifiquement au personnel hospitalier. Il se veut une introduction, d'accès facile, à une analyse sociologique de l'hôpital. 
L'auteur présente d'abord la sociologie comme discipline et explicite quelques notions fondamentales (interaction, communication, groupe, statut, rôle), nécessaires à l'intelligence de l'analyse qu'il se propose de faire. Les principales méthodes de recherche utilisées par les sociologues sont, aussi, brièvement présentées.

Le lecteur est, dès lors, prêt pour une analyse de la vie en milieu hospitalier. Cette analyse met spécialement l'emphase sur l'importance des communications et des relations interpersonnelles au sein de l'organisation hospitalière. L'auteur étudie successivement les rôles de malade, de médecin, d'infirmière et d'administrateur pour tenter d'éclairer les rapports complexes que nouent quotidiennement ces diverses catégories de personnes.

Cette approche, de type fonctionnaliste, a le mérite de rendre compréhensibles les comportements individuels en milieu hospitalier. Cependant elle comporte d'importantes limites, entre autres, celle de ne pas tenir compte de variables structurelles majeures. Par exemple, l'organisation formelle de l'hôpital y est tenue pour valeur négligeable; de même l'auteur ignore-t-il, en s'en tenant à une analyse des rôles et des statuts, l'importance des rapports de force entre les différents groupes professionnels impliqués dans le processus de distribution des soins hospitaliers pour expliquer la nature des relations entre les professionnels de la santé (médecin-infirmière, par exemple). En somme, on a parfois l'impression qu'il estime que le fonctionnement harmonieux de l'hôpital ne tient qu'à l'établissement de relations interpersonnelles cordiales entre les individus qui y vivent et $\mathrm{y}$ travaillent.

Cela dit, l'ouvrage de Swertz mérite d'être bien reçu; la formule de «l'ouvrage d'initiation », s'adressant à une catégorie spécifique d'individus implique nécessairement une certaine dose de simplification et de réductionnisme, avec tous les dangers que cela suppose. De ce côté, Swertz s'en tire bien. L'analyse qu'il fait de l'hôpital reste partielle, mais elle est claire et compréhensible; les professionnels de la santé y trouveront leur profit.

Université Laval
Confrontation at Winnipeg : Labour, Industrial Relations and the General Strike, by David Jay Bercuson, Montreal, McGill-Queen's University Press, 1974, 227 pp.

The general strike is a rare event and an extraordinary display of class polarization and trade union unity. Its widespread effect could tempt an observer to concentrate on the drama of the strike while neglecting the events leading up to it. The author of this volume has carefully avoided the error of viewing the general strike as merely the relationship between the parties from the time of negotiations until the eventual return to work. His examination of the Winnipeg general strike is accomplished with a full realization of the importance of the deteriorating labour-management relations of the prior decades. In large part, this is a study of the pressures and frustrations leading to the climatic confrontation in 1919.

More than one half of this volume is devoted to a review of the often volatile labour relations climate in Winnipeg. The initial chapter describes the early years of rapid economic expansion and the emerging municipal-industrial relationship. Intensified employer resistance to union recognition and bargaining is seen in the chapters on the depression of 1913-15 and the wartime years. Emphasis is placed on the growing frustration of workers and their unions when faced with rising living costs and a generally hostile employer reaction to their bargaining efforts. Employer resistance was widespread among the city's contract metal-working shops, particularly in comparison to the more cooperative relationships characterizing the building trades and the running trades of the railroads.

In later chapters, a series of negotiations and disputes begin to shape a collision course between trade unions and the city's employers. A worsening of labour-management relations led the unions to coordinate their efforts through sympathy strikes. The failure of a contract shop strike expanded the influence of the radical within the Winnipeg Trades Council. Moreover, workers throughout the West began to display a pronounced dissatisfaction with the more conservative among their leaders. This surge of employee mili- 